\title{
Inter-shelf nutrient transport from the East China Sea as a major nutrient source supporting winter primary production on the northeast South China Sea shelf
}

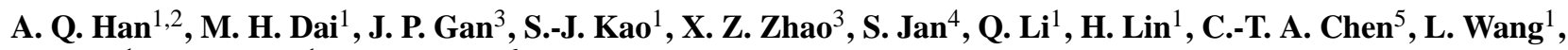 \\ J. Y. Hu ${ }^{1}$, L. F. Wang ${ }^{1}$, and F. Gong ${ }^{6}$ \\ ${ }^{1}$ State Key Laboratory of Marine Environmental Science, Xiamen University, Xiamen, China \\ ${ }^{2}$ Third Institute of Oceanography, State Oceanic Administration, Xiamen, China \\ ${ }^{3}$ Division of Environment, Hong Kong University of Science and Technology, Kowloon, Hong Kong, China \\ ${ }^{4}$ Institute of Oceanography, National Taiwan University, Taipei, Taiwan \\ ${ }^{5}$ Institute of Marine Geology and Chemistry, National Sun Yat-Sen University, Kaohsiung, Taiwan \\ ${ }^{6}$ State Key Laboratory of Satellite Ocean Environment Dynamics, Second Institute of Oceanography, State Oceanic \\ Administration, Hangzhou, China \\ Correspondence to: M. H. Dai (mdai@xmu.edu.cn)
}

Received: 25 November 2012 - Published in Biogeosciences Discuss.: 28 February 2013

Revised: 28 September 2013 - Accepted: 7 November 2013 - Published: 11 December 2013

\begin{abstract}
The East China Sea (ECS) and the South China Sea (SCS) are two major marginal seas of the North $\mathrm{Pa}$ cific with distinct seasonal variations of primary productivity. Based upon field observations covering both the ECS and the northern SCS (NSCS) during December 2008-January 2009, we examined southward long-range transport of nutrients from the ECS to the northeastern SCS (NESCS) carried by the China Coastal Current (CCC) driven by the prevailing northeast monsoon in wintertime. These escaped nutrients from the ECS shelf, where primary production (PP) was limited in winter, might however refuel the PP on the NESCS shelf at lower latitude, where the water temperature remained favorable, but river-sourced nutrients were limited. By combining the field observation of nitrate + nitrite $\left(\mathrm{NO}_{3}+\mathrm{NO}_{2}, \mathrm{DIN}\right)$ with our best estimate of volume transport of the CCC, we derived a first-order estimate for DIN flux of $1430 \pm 1024 \mathrm{~mol} \mathrm{~s}^{-1}$. Under the assumption that DIN was the limiting nutrient, such southward DIN transport would have stimulated $8.84 \pm 6.33 \times 10^{11} \mathrm{gC}$ of new production (NP), accounting for 33-74\% of the NP or 14-22\% of PP in winter on the NESCS shelf shallower than $100 \mathrm{~m}$.
\end{abstract}

\section{Introduction}

The continental shelf is well known for its high biological production, due to the abundant nutrients sourced from the land via river discharge and/or supplied through coastal upwelling and shoreward cross-shelf transport (Wollast, 1991, 1993; Ladd et al., 2005; Whitney et al., 2005; Sugimoto et al., 2009). Another possible transport pathway to redistribute dissolved and particulate nutrients and other materials is through alongshore currents, which can often be observed along the isotherms, featured with significant volume transports over long distance (Liu et al., 2000; Kao et al., 2003; Keafer et al., 2005; Whitney et al., 2005; Liu et al., 2007; Chen, 2008; Guo et al., 2012). However, the role of such alongshore transport of nutrients and the subsequent biological effects has rarely been examined, probably because it is commonly believed that the strongest gradients both chemically and biologically are important only in the cross-shelf dimension.

Two major continental shelves of the western North Pacific are those of the East China Sea (ECS) and the northern South China Sea (NSCS). These shelves are connected by the Taiwan Strait (TWS) (Fig. 1a). Hydrographic data characterize the China Coastal Current (CCC), which is driven by the northeast winter monsoon, to be one of the major water 

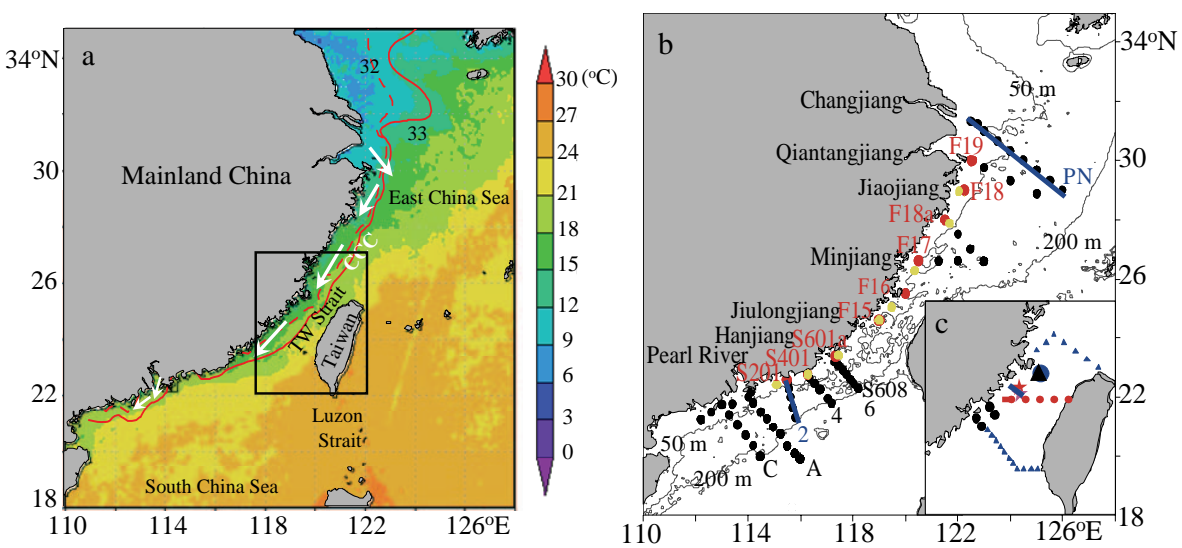

Fig. 1. (a) Map of the study area showing the East China Sea (ECS), the northern South China Sea (NSCS) as well as the Taiwan Strait (TWS). Red curves represent the schematic isohalines of the China Coastal Current (CCC) in the winters of 2008 (this study) and 2009 (Dai, unpublished data). The color background represents the mean sea surface temperature (SST) over December-February 2008. The SST image was sourced from http://gdata1.sci.gsfc.nasa.gov. The schematic CCC and the river plumes of the Changjiang and Pearl Rivers are marked by white arrows. (b) Map of the cruise track and sampling stations (black dots) in winter 2008. Red and yellow dots represent sampling stations within the CCC regime in the winters of 2008 and 2009, respectively. Transect PN in the ECS and transect 2 on the NSCS shelf are highlighted by blue lines. The $50 \mathrm{~m}$ and $200 \mathrm{~m}$ isobaths are also shown. (c) In the TWS, blue triangles, black dots and blue dots represent the stations sampled in January 2003 by Naik and Chen (2008), in November 2008 by Yan (2011) and in March 1997 by Liu et al. (2000), respectively. The locations involving bottom-mounted acoustic Doppler current profiler (bm-ADCP) deployments are marked by a pink star for site $\mathrm{C} 1\left(24.98^{\circ} \mathrm{N}, 119.48^{\circ} \mathrm{E}\right)$ from 1 October to 14 December 1999 and by a red star for site WC1 $\left(24.98^{\circ} \mathrm{N}, 119.48^{\circ} \mathrm{E}\right)$ from $1 \mathrm{January}$ to 28 February 2001. The black triangle located in the TWS refers to the study site of Fu et al. (1991). The blue line in the western TWS marks the transect width used for volume transport estimation based on the bm-ADCP. The red dashed line across the TWS is the transect that our numerical model adopted to simulate the current velocity, a fraction of which is shown as a solid red line within the CCC regime and was taken to estimate the volume transport of the CCC.

masses in the TWS (Jan et al., 2006, 2010), with relatively low sea surface temperature (SST) $\left(<18.0^{\circ} \mathrm{C}\right)$ and salinity (<33.0) (Fig. 1a). Chen (2008) reviews the winter nutrient distribution pattern both in the ECS and the TWS, and points out that the nutrient fluxes carried by the CCC through the TWS can be very significant. Based on our new observations together with the data available in the literature concerning nutrients and volume transport in the TWS, and supplemented with output from our numerical model, our study sought to quantify such a southward nutrient flux and to examine its significance. We demonstrated that such an intershelf nutrient flux was an important nutrient source sustaining the wintertime primary production (PP) on the shelf of the northeastern South China Sea (NESCS), which would otherwise be oligotrophic because of the limited river discharges and lack of shelf-break upwelling.

\section{Materials and methods}

\subsection{Study area}

The ECS has a broad shelf located in the subtropical to temperate zone, which is warm $\left(22.0-28.0^{\circ} \mathrm{C}\right)$ in summer and cold $\left(\sim 9.0\right.$ to $21.0^{\circ} \mathrm{C}$, Fig. 1a) in winter. Such a seasonal contrast in temperature is particularly profound on the inner shelf. The Changiiang is the largest river emptying into the ECS, with a peak discharge of $50000 \mathrm{~m}^{3} \mathrm{~s}^{-1}$ in summer and a minimum of $13000 \mathrm{~m}^{3} \mathrm{~s}^{-1}$ in winter (http://xxfb. hydroinfo.gov.cn/). The ECS is influenced by the nutrientenriched Changjiang discharge and Kuroshio subsurface water, and has a moderately high PP in summer, in the range 0.2-1.0 $\mathrm{gC} \mathrm{m}^{-2} \mathrm{~d}^{-1}$ (Chen, 1996; Chen and Wang, 1999; Chen et al., 2001; Gong et al., 2003, 2006, 2011). However, PP in winter is only one-tenth of that in summer probably due to low water temperature and light availability (Chen et al. 2001; Chiang et al., 2004; K. K. Liu et al., 2010; Umezawa et al., 2013), and, consequently, a significant amount of nutrients remain in the shelf waters of the ECS without being consumed.

The NSCS has a northeastward widened shelf located in the subtropical to tropical climate zone with a complicated coastline and topography. In summer, water on the shelf is rather warm at around $27.0^{\circ} \mathrm{C}$ (Han et al., 2012). In winter, the water temperature significantly dropped, to $18.0-24.0^{\circ} \mathrm{C}$ in the case of 2008 (Fig. 1a), which was however still considerably higher than that in the ECS in the same period. The Pearl River is the largest riverine nutrient source to the NSCS shelf with a discharge of $15500 \mathrm{~m}^{3} \mathrm{~s}^{-1}$ in summer and $1800 \mathrm{~m}^{3} \mathrm{~s}^{-1}$ in winter (http://xxfb.hydroinfo.gov.cn/). In summer, coastal upwelling plays an important role in supplying nutrients (Han et al., 2012). Notably, the PP in the NSCS in winter is maintained at similar levels to those in 
summer (0.8-1.0 $\mathrm{gC} \mathrm{m}^{-2} \mathrm{~d}^{-1}$; Chen and Chen, 2006; Wang et al., 2012). During this time period, the warm and oligotrophic Kuroshio surface water intrudes through the Luzon Strait and occupies a large area of the NSCS basin (Shaw, 1991; Hu et al., 2000), which significantly reduces the nutrient inventory in the upper ocean (Du et al., 2013).

The TWS is $\sim 180 \mathrm{~km}$ wide with an average depth of $\sim 60 \mathrm{~m}$ (Hong et al., 2011). Except in the winter monsoon period, the northward flow dominates (Wu and Hsin, 2005; Jan et al., 2006). In winter, the prevailing northeasterly wind drives the CCC flowing southwards. The current is confined within the narrow inner shelf with a water depth of $<50 \mathrm{~m}$. This coastal current originates from the ECS around the Changjiang estuary (Chang and Isobe, 2003; Chen, 2003; Lin et al., 2005; Guan and Fang, 2006) and is featured by low temperature, low salinity and high concentrations of nutrients as compared with the ambient seawater (Chen, 2003; Gong et al., 2003), primarily due to the large amount of nutrient discharge from the Changjiang. The CCC starts in mid-September, peaks from October to January and weakens thereafter (Jan and Chao, 2003; Lin et al., 2005; Wu and Hsin, 2005; Pan et al., 2012).

A number of studies have investigated the water volume transport through the TWS, either based on field measurements using shipboard acoustic Doppler current profilers (sbADCPs) (Liang et al., 2003; Wang et al., 2003), bottommounted acoustic Doppler current profilers (bm-ADCPs) (Lin et al., 2005; Jan et al., 2006), surface drifters (Qiu et al., 2011), or high-frequency radar (Zhu et al., 2008), or based on numerical models (Jan et al., 1998; Wu and Hsin, 2005; Wu et al., 2007; Fang et al., 2009). However, studies dedicated to assessing the total volume transport of the CCC and its variability and biogeochemical significance have not yet been conducted.

\subsection{Sampling and measurements}

An expedition on board the R/V Dongfanghong II was conducted on the ECS-TWS-NSCS shelves in winter, from 25 December 2008 to 9 January 2009. Cross-shelf transects covering both the ECS and NSCS shelves (marked by PN, 6, 4, 2, A, C; Fig. 1b) were investigated. Note that most of our sampling stations were located on the shelf $(<200 \mathrm{~m}$ isobaths). Intensive sampling was conducted in the regions shallower than $50 \mathrm{~m}$ along the coastline from the ECS to the NSCS shelf (Fig. 1b).

Samples were taken using Niskin bottles mounted onto a rosette sampler assembly, equipped with a conductivitytemperature-depth (CTD) recorder (Sea-Bird Co., SBE911). Nutrient samples were analyzed on board the ship using routine spectrophotometric methods with a Technicon AA3 Auto-Analyzer (Bran-Lube, GmbH) (Han et al., 2012, and references therein). The $n$ mol L${ }^{-1}$ levels of $\mathrm{PO}_{4}$ samples were frozen on board the ship and then measured in a shorebased laboratory following Ma et al. (2008). Samples for chlorophyll $a$ (Chl $a$ ) were filtered through $25 \mathrm{~mm}$ Whatman GF/F filters and then were immediately frozen until analysis. These samples were determined using a Turner fluorometer fitted with a red sensitive photomultiplier (Parsons et al., 1984)

\subsection{Model description}

To supplement the limited field observations, we adopted the regional ocean modeling system (ROMS) (Shchepetkin and McWilliams, 2005) to simulate the coastal current and to derive the mean volume transport of the CCC. ROMS is a free surface, hydrostatic, primitive equation of an ocean model. The Mellor-Yamada 2.5 turbulent sub-model, a bulkflux formulation for air-sea exchange and benthic boundary layer formulations, is embedded in the ROMS. The model domain was rectangular, extending from $1^{\circ} \mathrm{N}, 99^{\circ} \mathrm{E}$ in the southwest corner to about $49^{\circ} \mathrm{N}, 143.5^{\circ} \mathrm{E}$ in the northeast corner with its zonal axis directed eastwards and its meridional axis northwards. The model had an averaged horizontal grid size $<10 \mathrm{~km}$ and 30 vertical levels in stretched generalized terrain-following coordinates. The water depths of the model were obtained by merging ETOPO2 $\left(1 / 30^{\circ}\right.$ resolution) from the National Geophysical Data Center (USA) with the water depths digitized from navigation maps published by China's Maritime Safety Administration. The model was forced with $10 \mathrm{yr}$ (1999-2009) monthly mean $1 / 4 \times 1 / 4$ degree QuikSCAT winds and with climatological atmosphere fluxes from the National Centers for Environmental Prediction. Using the $10 \mathrm{yr}$ monthly mean wind field, we smoothed out the inter-annual variability. The initial conditions for the temperature and salinity fields were from the World Ocean Atlas 2005 (http://www.nodc.noaa. gov/OC5/WOA05/woa05data.html). The length of simulation was $20 \mathrm{yr}$, during which the model reached quasi-steady state. Along the southern and eastern open boundaries, climatological momentum and thermal fluxes from the Ocean General Circulation Model For the Earth Simulator (Sasaki et al., 2008) were implemented through the open boundary conditions of Gan and Allen (2005). The model was validated with observed sea surface temperature, dynamic height derived from Archiving, Validation, and Interpretation of Satellite Oceanographic data and other climatological mean conditions (Gan et al., 2013a). The climatological annual transport in the TWS was northward at about $1.1 \mathrm{~Sv}$ $\left(1 \mathrm{~Sv}=10^{6} \mathrm{~m}^{3} \mathrm{~s}^{-1}\right)$, close to the estimate of $1.09 \mathrm{~Sv}$ by $\mathrm{Wu}$ and Hsin (2005) and that of $1.2 \mathrm{~Sv}$ by Isobe (2008).

\section{Results and discussion}

\subsection{Hydrography}

Figure 2 is the potential temperature-salinity $(\theta-S)$ diagram covering both the ECS and NSCS shelf, showing a distinct hydrological difference between low-salinity water masses 


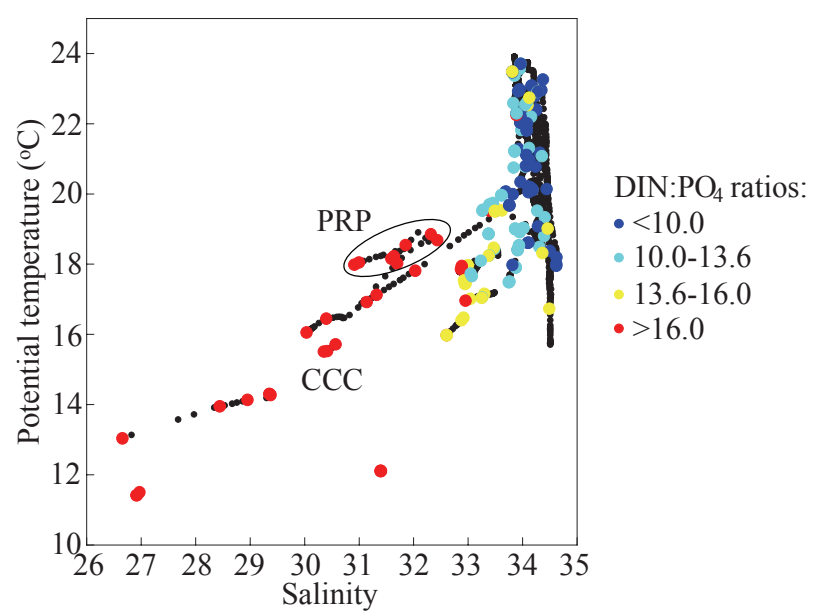

Fig. 2. Potential temperature $\left(\theta,{ }^{\circ} \mathrm{C}\right)$-salinity diagram shown in black dots. Superimposed are the ratios of DIN : $\mathrm{PO}_{4}$ in color bars based on nutrient measurements of discrete samples collected in winter 2008. Both the Pearl River plume (PRP) and the China Coastal Current (CCC) were featured by lower temperature and salinity but high DIN : $\mathrm{PO}_{4}$ ratios. See text for details.

and high-salinity water masses. The former water masses with salinity <33.0 may be grouped into two: one was the Pearl River plume (PRP) featured by higher temperature, and the other was the CCC characterized by a larger salinity range and lower temperature. The higher salinity water masses were primarily ECS and NSCS shelf waters.

Figure $3 \mathrm{a}$ and $\mathrm{b}$ further exhibit that a narrowband water mass with a low temperature of $12.1-13.0^{\circ} \mathrm{C}$ and a low salinity of 26.7-31.4 occupied the inner shelf of the ECS. This colder and fresher water mass hugging the coast was the CCC. Strong cross-shelf gradients in temperature from 12.1 to $23.2^{\circ} \mathrm{C}$ were observable, which was consistent with the satellite SST image during the same period (Fig. 1a). We also observed that the water temperature gradually increased from 12.1 to $16.9^{\circ} \mathrm{C}$ with the CCC flowing southwards from the Changjiang estuary mouth through the TWS (Fig. 3a).

Meanwhile, a water mass characterized by low temperature $\left(17.5-17.9^{\circ} \mathrm{C}\right)$ and low salinity (32.9-33.0) was observed in the nearshore region to the east of the Pearl River estuary mouth on the NESCS shelf (Fig. 3a and b). Since there was very limited freshwater discharge from the Pearl River in winter and the wind directed the plume southwestward, such a low temperature and salinity signal was very likely to have derived from the extension of the CCC. Another water mass with low salinity $(\sim 31.0)$ was observed to the west of the Pearl River estuary mouth (Fig. 3b). As distinguished from the $\theta-S$ diagram in Fig. 2, this water mass was the PRP. Away from the inner shelf, the NESCS was characterized by high temperature $\left(21.3-23.7^{\circ} \mathrm{C}\right)$ and high salinity (>34.0), reflective of the influence from the Kuroshio intrusion (Chen et al., 2010).

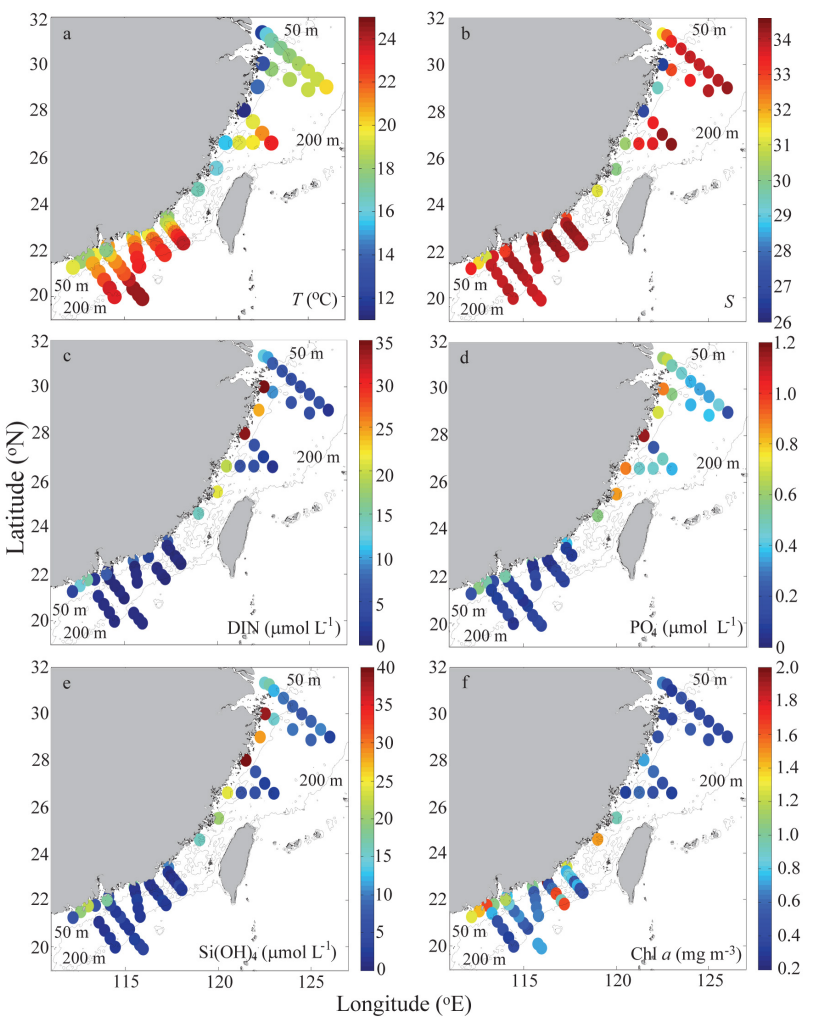

Fig. 3. Surface distributions of temperature $(T)(\mathbf{a})$, salinity $(S)(\mathbf{b})$, DIN $\left(\mathrm{NO}_{3}+\mathrm{NO}_{2}\right)(\mathbf{c}), \mathrm{PO}_{4}(\mathbf{d}), \mathrm{Si}(\mathrm{OH})_{4}(\mathbf{e})$ and $\mathrm{Chl} a$ (f) on the shelves of East China Sea and northern South China Sea as well as in the Taiwan Strait in winter 2008.

We further used our field data collected in the ECS (Fig. 4a and $b$ ) and the NSCS shelves (Fig. 5a and b) to give a transsectional view of the distinctive CCC. At transect PN, the $\mathrm{CCC}$ featured low temperature $\left(12.1-16.5^{\circ} \mathrm{C}\right)$ and low salinity (31.4-32.9), and occupied the inner shelf with a water depth mostly shallower than $50 \mathrm{~m}$. Seaward from the CCC, both temperature and salinity increased gradually and were vertically well mixed as reported previously (Hama et al., 1997; Kim et al., 2009).

At transect 2 crossing the NSCS shelf, we saw a similar pattern with vertically well mixed colder and less saline water nearshore (Fig. 5a and b) except for some downwelling structures with cold water $\left(18.0-18.7^{\circ} \mathrm{C}\right)$ extending from the CCC sloping downward along the bottom towards offshore (80-100 m isobath) (Fig. 5a). The salinity signal of this downwelling structure appeared less pronounced than the temperature signal, probably due to mixing with the ambient saline oceanic water (Fig. 5b). Note that S. M. Liu et al. (2010) report a similar pattern in this area. 


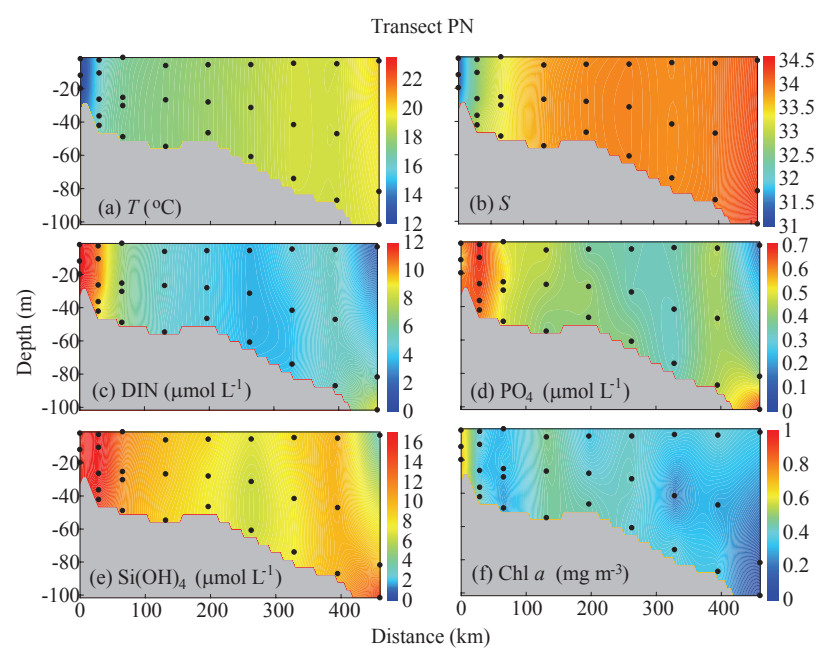

Fig. 4. Trans-sectional distributions of $T$ (a), $S$ (b), DIN (c), $\mathrm{PO}_{4}$ (d), $\mathrm{Si}(\mathrm{OH})_{4}(\mathbf{e})$, and $\mathrm{Chl} a$ (f) along transect $\mathrm{PN}$ in the East China Sea in winter 2008 .

\subsection{Distribution of nutrients and Chl $a$}

\subsubsection{Surface distribution}

The surface water occupied by the CCC displayed very high nutrient levels with their highest concentrations of DIN $\sim 35.0 \mu \mathrm{mol} \mathrm{L}-1, \mathrm{PO}_{4} \sim 0.89 \mu \mathrm{mol} \mathrm{L}^{-1}$, and $\mathrm{Si}(\mathrm{OH})_{4} \sim 38.5 \mu \mathrm{mol} \mathrm{L}^{-1}$ being located immediately to the south of the Changjiang estuary mouth (Fig. 3c-e). The offshore shelf water was characterized by lower nutrients due to dilution by the oligotrophic Kuroshio surface water and/or due to uptake by phytoplankton in the warmer and clearer water. Nevertheless, the nutrient concentrations overall stayed at high levels over the entire ECS with concentration ranges of $9.6-1.5 \mu \mathrm{mol} \mathrm{L}^{-1}$ for DIN, 0.58 $0.15 \mu \mathrm{mol} \mathrm{L}^{-1}$ for $\mathrm{PO}_{4}$, and $15.4-3.0 \mu \mathrm{mol} \mathrm{L}^{-1}$ for $\mathrm{Si}(\mathrm{OH})_{4}$. It is interesting to note, however, the Chl $a$ values were not concomitantly high, being $0.3-0.7 \mathrm{mg} \mathrm{m}^{-3}$ (Fig. 3f). Low Chl $a$ in the ECS in winter might be attributable to temperature and light limitation as suggested by previous researchers (Chen et al. 2001; Chiang et al., 2004; K. K. Liu et al., 2010; Umezawa et al., 2013).

Compared with the ECS, Chl $a$ values on the NSCS shelf were higher. The PRP in its southwest region had the highest nutrient concentrations of $\sim 14.8 \mu \mathrm{mol} \mathrm{L}^{-1}$ for DIN, $\sim 0.51 \mu \mathrm{mol} \mathrm{L}^{-1}$ for $\mathrm{PO}_{4}$ and $\sim 21.9 \mu \mathrm{mol} \mathrm{L}^{-1}$ for $\mathrm{Si}(\mathrm{OH})_{4}$ (Fig. 3c-e). Correspondingly, Chl $a$ up to $1.6 \mathrm{mg} \mathrm{m}^{-3}$ was observed (Fig. 3f). Nutrients on the NESCS inner shelf were also relatively abundant, where DIN, $\mathrm{PO}_{4}$ and $\mathrm{Si}(\mathrm{OH})_{4}$ were $6.6-8.0 \mu \mathrm{mol} \mathrm{L}^{-1}, 0.38-0.54 \mu \mathrm{mol} \mathrm{L}^{-1}$ and $10.4-17.6 \mu \mathrm{mol} \mathrm{L}^{-1}$, respectively (Fig. 3c-e). They all showed a seaward decreasing pattern. In contrast, the outer shelf area was characterized by very low nutrient concentrations in the range $<0.9 \mu \mathrm{mol} \mathrm{L}^{-1}$ for DIN, $<0.12 \mu \mathrm{mol} \mathrm{L}^{-1}$

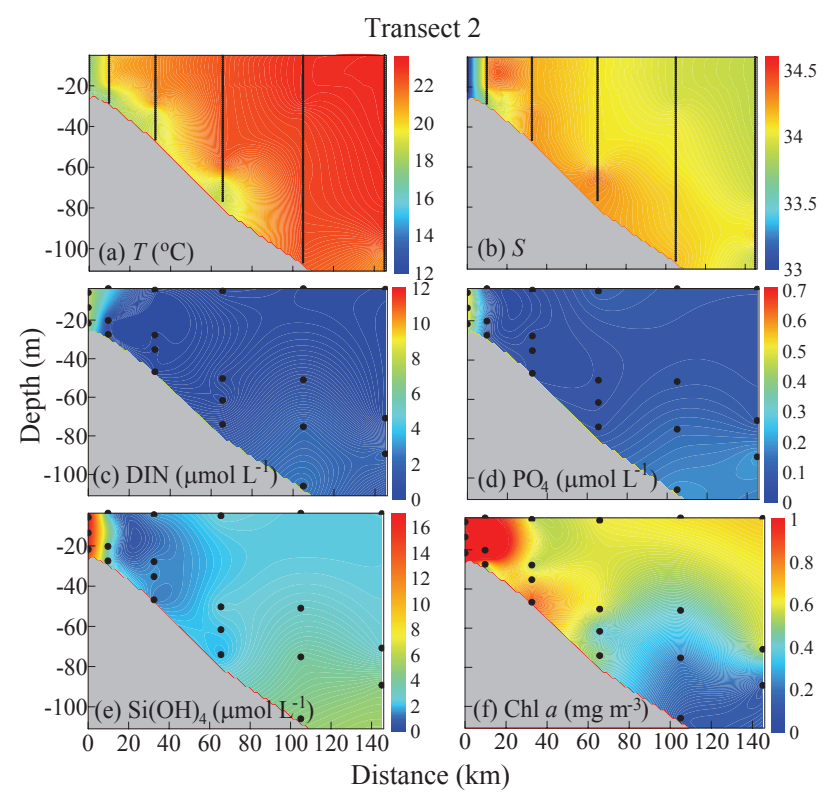

Fig. 5. Trans-sectional distributions of $T$ (a), $S$ (b), DIN (c), $\mathrm{PO}_{4}$ (d), $\mathrm{Si}(\mathrm{OH})_{4}(\mathbf{e})$, and $\mathrm{Chl} a$ (f) along transect 2 of the northern South China Sea shelf in winter 2008.

for $\mathrm{PO}_{4}$ and $<3.9 \mu \mathrm{mol} \mathrm{L}{ }^{-1}$ for $\mathrm{Si}(\mathrm{OH})_{4}$, reflecting an oligotrophic condition. Within the $\sim 100 \mathrm{~m}$ isobath of the NSCS shelf, we saw higher values of $\mathrm{Chl} a$ of $0.6-2.0 \mathrm{mg} \mathrm{m}^{-3}$ in the northeastern part relative to those in the southwestern part (0.4-0.7 $\mathrm{mg} \mathrm{m}^{-3}$ ) (Fig. 3f).

The winter enhancement in Chl $a$ on the NESCS shelf was, as a matter of fact, a common feature as demonstrated by the long-term MODIS (Moderate Resolution Imaging Spectroradiometer) Chl $a$ data. As shown in Fig. 6a, the MODIS Chl $a$ on the NESCS shelf ranged from $\sim 0.5$ to $2.5 \mathrm{mg} \mathrm{m}^{-3}$, visibly higher than that in the southwestern part of the NSCS. The average Chl $a$ inventory, calculated based on in situ $\mathrm{Chl} a$ profiles at stations within the CCC, further suggested that the enhanced winter biomass on the NESCS shelf was even higher than that in the ECS (Fig. 6b). Along the CCC regime, the Chl $a$ inventory at station YZE located in transect $\mathrm{PN}$ of the ECS shelf was $12.0 \mathrm{mg} \mathrm{m}^{-2}$. In contrast, higher averaged Chl $a$ inventory was found on the NESCS shelf within the CCC, being 54.1, 20.5, and $15.6 \mathrm{mg} \mathrm{m}^{-2}$ at stations S601a, S401, and S201, respectively. As mentioned above, the winter lower biomass in the ECS is probably limited by the low temperature and/or light availability while such limiting factors might not be issues for the wintertime primary productivity on the NESCS shelf. Note that recent studies find that the NESCS shelf has higher new production (NP) of $\sim 0.15-0.34 \mathrm{gC} \mathrm{m}^{-2} \mathrm{~d}^{-1}$ in wintertime (Chen and Chen, 2006; Wang et al., 2012) than that in summer $(\sim 0.06-$ $0.17 \mathrm{gC} \mathrm{m}^{-2} \mathrm{~d}^{-1}$; Chen and Chen, 2006). 

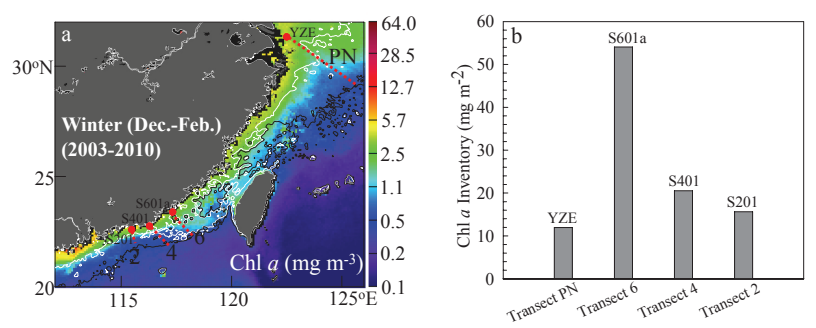

Fig. 6. (a) Averaged Moderate Resolution Imaging Spectroradiometer (MODIS) Chl $a\left(\mathrm{mg} \mathrm{m}^{-3}\right)$ with $9 \mathrm{~km}$ spatial resolution over the ECS-TWS-NSCS shelf in winter (December-February) from 2003 to 2010 (http://oceancolor.gsfc.nasa.gov). White and black contours indicate the $50 \mathrm{~m}$ and $100 \mathrm{~m}$ isobaths. Comparison between our field measured surface Chl $a$ from transects 2 and 6 on the northeastern South China Sea (NESCS) shelf during the cruise with the monthly average MODIS value of the same month as the cruise revealed a good correlation coefficient $\left(R^{2}=0.77\right)$, suggesting that these MODIS data were generally in order. (b) Average Chl $a$ inventory in $\mathrm{mg} \mathrm{m}^{-2}$, calculated by integrating the $\mathrm{Chl} a$ concentrations of the water column at individual stations (red dots) within the CCC on the ECS and the NESCS shelf measured in winter 2008 showing enhanced Chl $a$ inventory in the NESCS. Note that the red dash lines indicate the locations of transects PN, 6, 4, and 2, respectively.

\subsubsection{Vertical distribution}

Similar to the cross-shelf pattern of temperature and salinity, transect PN displayed a vertically homogeneous feature in nutrient distribution across the shelf (Fig. 4c-e). DIN in the nearshore water column was as high as $9.3-12.5 \mu \mathrm{mol} \mathrm{L}^{-1}$, but it rapidly decreased seaward to $3.6-7.0 \mu \mathrm{mol} \mathrm{L}^{-1}$. $\mathrm{PO}_{4}$ and $\mathrm{Si}(\mathrm{OH})_{4}$ had similar patterns with concentrations ranging, respectively, from $0.51-0.68$ and $15.1-16.9 \mu \mathrm{mol} \mathrm{L}^{-1}$ in the nearshore to $0.15-0.49$ and $3.0-12.3 \mu \mathrm{mol} \mathrm{L}^{-1}$ offshore. The Chl $a$ distribution in transect PN was also vertically homogeneous in the inner and middle shelves, with a low value of $\sim 0.7 \mathrm{mg} \mathrm{m}^{-3}$ in the $\mathrm{CCC}$ and even lower values of $0.3-$ $0.5 \mathrm{mg} \mathrm{m}^{-3}$ on the shelf, regardless of the high nutrient concentration (Fig. 4f).

Nutrients on the NSCS shelf also showed a vertically well mixed feature in their distribution as demonstrated in Fig. 5c-e for transect 2. Again, nutrient concentrations in the CCC near the coast were very high, with values of 7.8-8.0 $\mu \mathrm{mol} \mathrm{L}^{-1}$ for DIN, $0.51-0.54 \mu \mathrm{mol} \mathrm{L}^{-1}$ for $\mathrm{PO}_{4}$, and $16.6-17.6 \mu \mathrm{mol} \mathrm{L}^{-1}$ for $\mathrm{Si}(\mathrm{OH})_{4}$. Consistent with the high levels of nutrients, Chl $a$ in the CCC on the NESCS shelf was enhanced to $\sim 1.0 \mathrm{mg} \mathrm{m}^{-3}$. This was in clear contrast to the nearshore regime in the ECS. The difference in the responses to the high nutrients was very likely related to the warmer temperature $\left(\sim 18.0^{\circ} \mathrm{C}\right)$ and more favorable light penetration on the inner NESCS shelf. Beyond the CCC domain of the NESCS shelf, nutrients decreased seaward, with a DIN of $\sim 0.5 \mu \mathrm{mol} \mathrm{L}^{-1}, \mathrm{PO}_{4}$ of $\sim 0.10 \mu \mathrm{mol} \mathrm{L}^{-1}$ and $\mathrm{Si}(\mathrm{OH})_{4}$ of $\sim 2.5 \mu \mathrm{mol} \mathrm{L}^{-1}$, while the corresponding Chl $a$
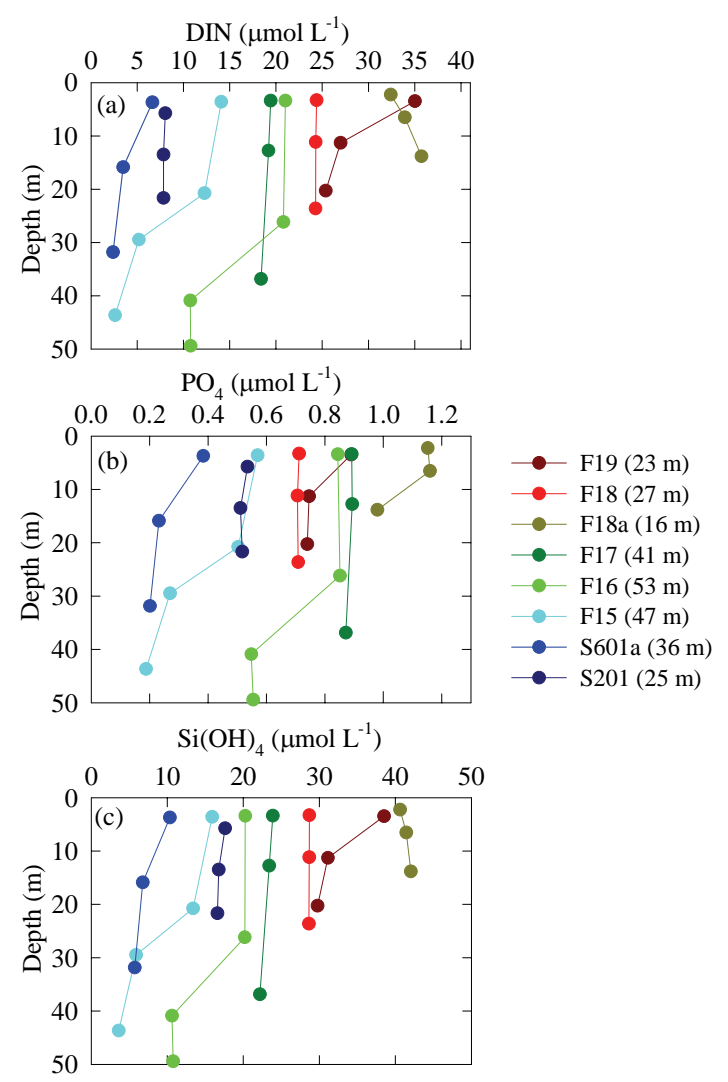

Fig. 7. Vertical profiles of nutrients (a) DIN, (b) $\mathrm{PO}_{4}$, and (c) $\left.\mathrm{Si}(\mathrm{OH})_{4}\right)$ in the China Coastal Current stream from the East China Sea (ECS) to the northeastern South China Sea (NESCS) shelf via the Taiwan Strait (TWS) in winter 2008. Note that stations F19F17 are in the ECS segment, F16-F15 in the TWS segment and S601a-S201 in the NESCS segment. The water depth is shown in parentheses following the station numbers.

was $0.6-0.8 \mathrm{mg} \mathrm{m}^{-3}$, slightly higher than that on the ECS shelf (Fig. 4f).

The overall hydrological and biogeochemical properties, therefore, showed a clear picture of the CCC streaming from the ECS shelf to the NESCS shelf in wintertime. To understand the CCC further, detailed characteristics of the nutrients in the CCC domain were examined.

\subsection{Nutrient characteristics of the CCC}

Figure 7 illustrates vertical nutrient profiles from the stations along the CCC pathway. Here, the CCC exhibited a clear decreasing gradient from the ECS to the NESCS shelf via the TWS. For example, the DIN concentration was 24.3$35.7 \mu \mathrm{mol} \mathrm{L}^{-1}$ in the ECS segment, $2.4-14.1 \mu \mathrm{mol} \mathrm{L}^{-1}$ in the TWS segment and $2.4-8.0 \mu \mathrm{mol} \mathrm{L}^{-1}$ in the NESCS segment (Fig. 7a). Spatial variations of $\mathrm{PO}_{4}$ and $\mathrm{Si}(\mathrm{OH})_{4}$ were similar to those of DIN (Fig. 7b and c), and were highest in the ECS segment but lowest in the NESCS segment. 


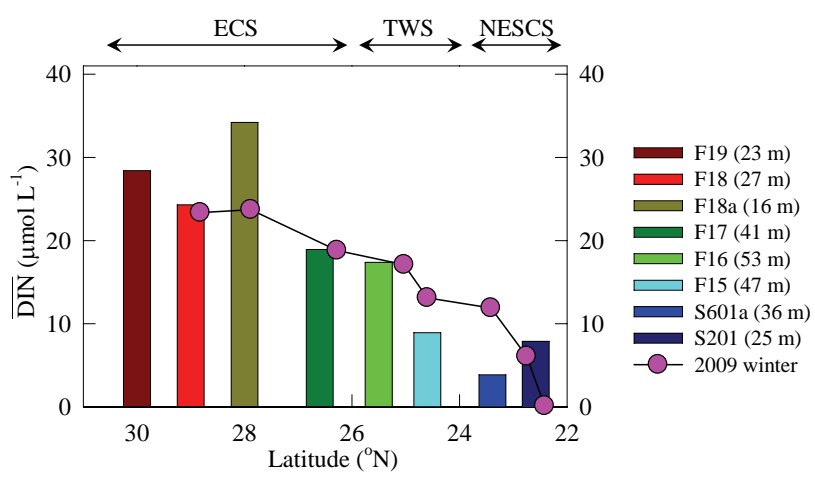

Fig. 8. Depth-averaged concentrations of DIN $(\overline{\mathrm{DIN}})$ in winter 2008 (color bars) and winter 2009 (pink dots) plotted against latitude, showing the southwards decreasing trend of $\overline{\mathrm{DIN}}$. The water depth is shown in parentheses following the station numbers.

It should also be noted that some point sources from local rivers might add nutrients along the $\mathrm{CCC}$ pathway. For example, at stations F18a and F16 off the Jiaojiang and Minjiang estuary mouths, higher concentrations and lower salinity ( $\sim 26.9$ at F18a and 30.05-32.33 at F16) can be seen compared to those upstream $(\sim 29.4$ at F18 and 30.37-30.58 at F17) (Figs. 1b, 3 and 7). Such impacts from point sources have already been recognized in previous studies (Wong et al., 2000; Lee and Chao, 2003; Naik and Chen, 2008).

In addition, most of the nutrient concentrations showed little vertical gradients at a water depth $<30 \mathrm{~m}$ throughout the CCC segments. In contrast, at the sites with water depth $>30 \mathrm{~m}$, surface nutrient concentrations were considerably higher than those at the bottom (Fig. 7). For example, the surface nutrients at station F15 in the TWS segment in winter 2008 were $14.1 \mu \mathrm{mol} \mathrm{L}^{-1}$ for DIN, $0.57 \mu \mathrm{mol} \mathrm{L}^{-1}$ for $\mathrm{PO}_{4}$, and $15.9 \mu \mathrm{mol} \mathrm{L}^{-1}$ for $\mathrm{Si}(\mathrm{OH})_{4}$, much higher than those of the bottom waters, which were $2.6 \mu \mathrm{mol} \mathrm{L}^{-1}$ for DIN, $0.19 \mu \mathrm{mol} \mathrm{L}^{-1}$ for $\mathrm{PO}_{4}$, and $3.6 \mu \mathrm{mol} \mathrm{L}^{-1}$ for $\mathrm{Si}(\mathrm{OH})_{4}$. Compared to winter 2008, the nutrient structures in the CCC obtained in winter 2009 had a similar profile shape but with stronger vertical mixing (data not shown). Nutrients at station F15 were almost identical in the upper layer as observed in the two winters. In the bottom water, much higher nutrient concentrations of $9.3 \mu \mathrm{mol} \mathrm{L}{ }^{-1}$ for DIN, $0.51 \mu \mathrm{mol} \mathrm{L}^{-1}$ for $\mathrm{PO}_{4}$, and $10.1 \mu \mathrm{mol} \mathrm{L}{ }^{-1}$ for $\mathrm{Si}(\mathrm{OH})_{4}$ were observed in winter 2009. The elevated bottom nutrient concentration in 2009 might have been induced either from particle remineralization in the water column or regeneration from the sediment (Kao et al., 2003; Liu et al., 2007).

We used the depth-averaged concentration of DIN ( $\overline{\mathrm{DIN}})$ based on the trapezoid rule at each station along the CCC to represent the mean DIN concentration in the CCC, the variation of which largely followed the surface distribution (Fig. 3). Figure 8 shows that the $\overline{D I N}$ concentration in both winters generally decreased southward with latitude, from 34.2 to $1.8 \mu \mathrm{mol} \mathrm{L}^{-1}$ in winter 2008 and from 23.7 to $0.1 \mu \mathrm{mol} \mathrm{L}{ }^{-1}$ in winter 2009 . Such a trend was however slightly disrupted at stations F18a and S201, where point nutrient sources from the local rivers were again visible. Note that the freshwater discharges from the Jiaojiang and Minjiang are less than one-thirteenth of those of the Changjiang in winter (Yu, 1992; Wang et al., 2011), and it was considered that the contributions of the point sources were quite limited due to the much smaller river discharge.

Within the TWS segment (e.g., at station F15), DIN concentrations were $8.9 \mu \mathrm{mol} \mathrm{L}^{-1}$ in winter 2008 and $13.1 \mu \mathrm{mol} \mathrm{L}^{-1}$ in winter 2009 (Figs. $1 \mathrm{~b}$ and 8). Previous studies report that the average nitrate concentration in the TWS between $\sim 24.2^{\circ} \mathrm{N}, 118.5^{\circ} \mathrm{E}$ and $\sim 26.2^{\circ} \mathrm{N}, 120.4^{\circ} \mathrm{E}$ ranged 13.0-15.0 $\mathrm{mol} \mathrm{L}^{-1}$ in January 2003 (Chen, 2008; Naik and Chen, 2008). The average nitrate concentration in the northern TWS $\left(\sim 25.3^{\circ} \mathrm{N}, 120.0^{\circ} \mathrm{E}\right)$ was $\sim 14.0 \mu \mathrm{mol} \mathrm{L}^{-1}$ in the surface and $\sim 4.0 \mu \mathrm{mol} \mathrm{L}^{-1}$ in the bottom in March 1997 (Liu et al., 2000). Another study shows that DIN concentration in the southern TWS $\left(\sim 24.4^{\circ} \mathrm{N}, 118.7^{\circ} \mathrm{E}\right)$ was $7.7-$ $20.1 \mu \mathrm{mol} \mathrm{L}^{-1}$ in November 2008 (Yan, 2011). These data sets, though limited, do not show any noticeable inter-annual variation in DIN concentration in the TWS segment of the CCC. In our study, we used averaged water column concentration based on our own data sets collected in the two consecutive winters (2008 and 2009) to represent the DIN level in the TWS segment of the CCC, and the value was $11.0 \pm 2.0 \mu \mathrm{mol} \mathrm{L}^{-1}$.

The characteristic of the CCC can also be shown from the nutrient stoichiometry. The $\theta-S$ diagram in Fig. 2 superimposed by DIN : $\mathrm{PO}_{4}$ ratios has already distinguished that the cold and diluted waters were associated with higher DIN : $\mathrm{PO}_{4}$ ratios (> $\left.16: 1\right)$ while lower DIN : $\mathrm{PO}_{4}$ ratio water was associated with high-salinity waters. To characterize the nutrients in the $\mathrm{CCC}$ further, the relationships between DIN and $\mathrm{PO}_{4}$, and $\mathrm{Si}(\mathrm{OH})_{4}$ and DIN in winter were constructed (Fig. 9). In detail, the DIN : $\mathrm{PO}_{4}$ ratio in the CCC was $\sim 33.8$ (Fig. 9a), substantially lower than that in the Changjiang (100-160: 1, Liu et al., 2009). The rapid reduction of the DIN : $\mathrm{PO}_{4}$ ratio from the Changjiang to the CCC might be induced by mixing with the ambient seawater with low DIN : $\mathrm{PO}_{4}$ ratios as shown in Figs. 2 and 9 and in previous studies (Chai et al., 2006; Zhang et al., 2007; Lui and Chen, 2011). $\mathrm{Si}(\mathrm{OH})_{4}$ : DIN ratios in the $\mathrm{CCC}$ regime were not that different from the rest of the study area (Fig. 9b). This was likely due to the fact that the Changjiang, the entire ECS and the NSCS shelves all have a close to $1: 1$ $\mathrm{Si}(\mathrm{OH})_{4}$ : DIN ratio (Fig. 9b).

In summary, the hydrochemical characteristics of the CCC were distinctly different from those of the ambient shelf water. This nutrient-enriched CCC was primarily sourced from the ECS and was interconnected with the ECS shelf and the NESCS shelf via the western TWS. 

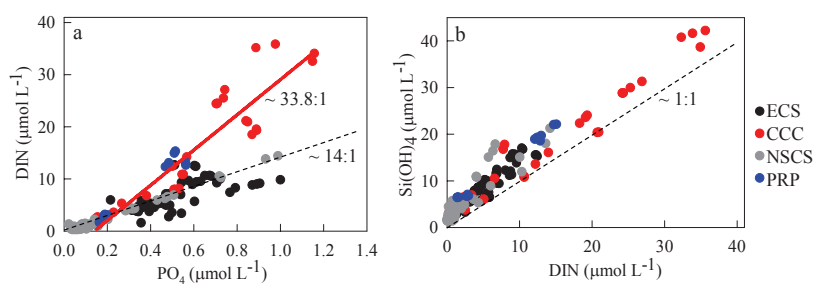

Fig. 9. Correlations between $\mathrm{DIN}$ and $\mathrm{PO}_{4}$ (a), and between $\mathrm{Si}(\mathrm{OH})_{4}$ and DIN (b) in the different water masses on the East China Sea (ECS) and the northern South China Sea (NSCS) shelves and in the Taiwan Strait (TWS) in winter 2008. The red line in panel (a) indicates the regression line of DIN and $\mathrm{PO}_{4}$ in the China Coastal Current (CCC), and the black line in panel (a) indicates the potential end-member with low DIN : $\mathrm{PO}_{4} \sim 14: 1$. The dashed line in panel (b) represents the $\mathrm{Si}(\mathrm{OH})_{4}: \mathrm{DIN}$ ratio $\sim 1: 1$. PRP stands for Pearl River plume.

\subsection{CCC volume transport across the western TWS}

\subsubsection{Field observations}

During October-December 1999 and January-February 2001, along-strait current velocities at sites $\mathrm{C1}$ and WC1 in the western TWS were measured using a bm-ADCP (Fig. 1c). These time-series data at $\mathrm{C} 1$ were explicitly introduced by Lin et al. (2005). Briefly, the current velocity was primarily southwards over the whole water column with small vertical gradient and generally fluctuated with the northeast monsoon (see Figs. 3 and 10 in Lin et al., 2005). The low-passed current velocity was then used to estimate the volume transport $(T, \mathrm{~Sv})$ assuming the width of the CCC: the distance between the mooring location and the coastline (from $24.848^{\circ} \mathrm{N}$ and $119.680^{\circ} \mathrm{E}$ to $25.043^{\circ} \mathrm{N}$ and $119.326^{\circ}$ E, Fig. 1c) is $\sim 40 \mathrm{~km}$, and the current velocity across the CCC is uniform (Fig. 10).

Very dynamic, $T$ varied from -1.12 to $0.45 \mathrm{~Sv}$ with a period of 5-10 days, roughly consistent with northeasterly wind variability associated with the local synoptic weather system (Fig. 10a). If we averaged all the negative values (or southward transport), the mean was $-0.33 \pm 0.28 \mathrm{~Sv}$ (with the standard deviation representing southward transport variability). On the other hand, the average of all positive values (or northward transport) was $0.12 \pm 0.08 \mathrm{~Sv}$ (Fig. 10a). The net southward $T$ was therefore estimated to be $0.18 \mathrm{~Sv}$ with a standard deviation of $0.31 \mathrm{~Sv}$. This estimate was consistent with the derived $T$ of $0.1-0.2 \mathrm{~Sv}$ based on the current velocity $\left(0.1-0.2 \mathrm{~m} \mathrm{~s}^{-1}\right.$ ) observed in the same winter (Liang et al., 2003) although the latter observation was conducted further north of $\mathrm{C} 1$ with different water depth and width of the CCC. The volume transport in winter 2001 followed a similar pattern to that in 1999 , but had lower values ranging from -0.66 to $0.33 \mathrm{~Sv}$ with a net southward transport of $0.03 \pm 0.20 \mathrm{~Sv}$ (Fig. 10b). This value of the volume transport was comparable to the derived $T$ of $\sim 0.05 \mathrm{~Sv}$ based
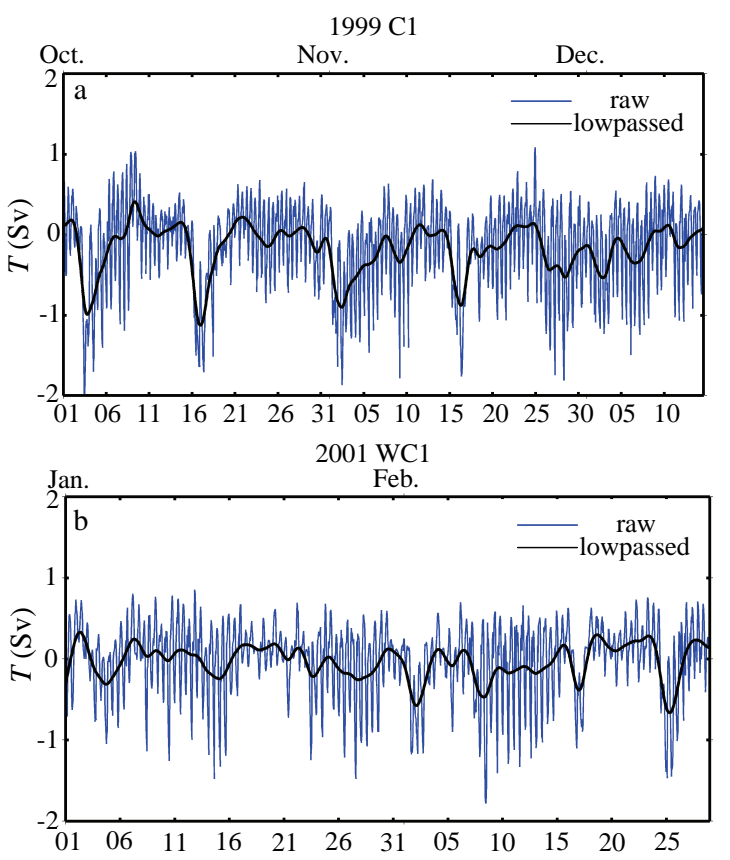

Fig. 10. Two sets of time series of along-strait current volume transport $\left(T\right.$, in units of $\left.\mathrm{Sv}, 1 \mathrm{~Sv}=10^{6} \mathrm{~m}^{3} \mathrm{~s}^{-1}\right)$ in the China Coastal Current (CCC) stream in the western Taiwan Strait (TWS) at site $\mathrm{C} 1\left(24.98^{\circ} \mathrm{N}, 119.48^{\circ} \mathrm{E}\right)$ and $\mathrm{WC} 1\left(24.98^{\circ} \mathrm{N}, 119.48^{\circ} \mathrm{E}\right)$ from 1 October to 14 December 1999 based on Lin et al. (2005) (a) and from 1 January to 28 February 2001 as summarized in Jan et al. (2006) (b). The two sites are very close and have a water depth of $\sim 44 \mathrm{~m}$ (see Fig. 1c for locations). The current velocities were measured using bm-ADCPs. Detailed information concerning the deployments of bm-ADCPs is introduced by Lin et al. (2005) and Jan et al. (2006). The $30 \mathrm{~h}$ low-pass-filtered volume transport $T$ is shown in solid lines as calculated by assuming the $\mathrm{CCC}$ width of $40 \mathrm{~km}$ (from $24.848^{\circ} \mathrm{N}$ and $119.680^{\circ} \mathrm{E}$ to $25.043^{\circ} \mathrm{N}$ and $\left.119.326^{\circ} \mathrm{E}\right)$. Negative values represent southward transport.

on the velocity $\left(\sim 0.05 \mathrm{~m} \mathrm{~s}^{-1}\right)$ observation in winter 1987 by Fu et al. (1991), or the $T$ value of 0.06-0.12 Sv based on the velocity $\left(0.1-0.2 \mathrm{~m} \mathrm{~s}^{-1}\right)$ measured by Pan et al. (2012). Again, these different observations were conducted at different locations, and the $T$ estimate was based on different water depths and widths of the CCC (Table 1). The above volume transport values obviously had inter-annual variations, the reasons for which were unclear. One possible driver for such temporal changes could be related to the inter-annual variations of wind speed, or the strength of the northeastern monsoon, a primary driver of the CCC. Indeed, based on QuickSCAT monthly wind data (http://www.ssmi.com/qscat/ qscat_browse.html), the wind speed was $\sim 15 \mathrm{~m} \mathrm{~s}^{-1}$ in 1999 and $\sim 11 \mathrm{~m} \mathrm{~s}^{-1}$ in winter 2001 , and we saw larger transport in 1999. Unfortunately, the limited observational data have not allowed quantitative examination between the CCC transport and the wind stress, and this warrants further research. 
Table 1. Velocity and volume transport in the China Coastal Current across various transects in the Taiwan Strait.

\begin{tabular}{|c|c|c|c|c|c|}
\hline $\begin{array}{l}\text { Station/transect } \\
\text { location }\end{array}$ & $\begin{array}{r}\text { Average water depth of the } \\
\text { station or along the } \\
\text { transect }(\mathrm{m})\end{array}$ & Zonal distance $(\mathrm{km})$ & $\begin{array}{l}\text { Velocity } \\
\left(\mathrm{m} \mathrm{s}^{-1}\right)\end{array}$ & References & $T(\mathrm{~Sv})^{\mathrm{a}}$ \\
\hline $24.98^{\circ} \mathrm{N}, 119.48^{\circ} \mathrm{E}$ & 40 & 40 & -0.11 & See text & -0.18 \\
\hline $24.98^{\circ} \mathrm{N}, 119.48^{\circ} \mathrm{E}$ & 40 & 40 & -0.02 & See text & -0.03 \\
\hline $25.27^{\circ} \mathrm{N}, 119.98^{\circ} \mathrm{E}$ & 30 & 30 & -0.05 & Fu et al. (1991) & -0.05 \\
\hline $24.6^{\circ} \mathrm{N}, 118.84-119.0^{\circ} \mathrm{E}$ & $25-44$ & 17.5 & $-0.17 \pm 0.12^{\mathrm{b}}$ & Model result, this study & $-0.13 \pm 0.09$ \\
\hline
\end{tabular}

\subsubsection{Model verification and model results}

The field observations in the TWS have thus far been very limited. Moreover, they were generally short-term with limited spatial and temporal coverage, and so the inter-annual variability cannot thus be resolved based solely on these observational data. We thus adopted a numerical model driven by climatological forcing in order to simulate the current velocity across the TWS in the entire winter (December, January, and February) and subsequently to estimate the climatological volume transport better.

Figure 11 shows the modeled climatological along-shore current velocity along $24.6^{\circ} \mathrm{N}$ across the TWS in winter. The model-derived velocity structure exhibited two segments: one was the southward CCC, which was confined in a narrow zone hugging the west coast of the TWS; the other was the northward flowing Taiwan Strait Warm Current located in the rest of the TWS. Such a pattern was consistent with previous results from in situ observations, supporting the validity of our numerical model (Fu et al., 1991; Liang et al., 2003; Chen et al., 2010).

It is important to note that our model-derived current velocity field displays a zonal velocity gradient within the CCC regime (Fig. 11), a feature not easily captured by a fixed mooring station observation. The modeled velocity within the CCC essentially decreased from $\sim 0.3 \mathrm{~m} \mathrm{~s}^{-1}$ nearshore to $\sim 0.1 \mathrm{~m} \mathrm{~s}^{-1}$ offshore. Such a pattern was consistent with the sb-ADCP-based survey around a similar location with values of $0.1-0.2 \mathrm{~m} \mathrm{~s}^{-1}$ (Liang et al., 2003).

To further check our model results, the modeled current velocity at station $\mathrm{F} 15\left(24.6^{\circ} \mathrm{N}\right.$ and $\left.119.0^{\circ} \mathrm{E}\right)$ was chosen and compared with the in situ observation at station WC1 in winter 2001, which was at a similar location and under a similar wind forcing $\left(\sim 11 \mathrm{~m} \mathrm{~s}^{-1}\right)$. The modeled velocity vertical profile at station $\mathrm{F} 15$ showed a decreasing pattern, from $0.29 \mathrm{~m} \mathrm{~s}^{-1}$ in the upper layer to $<0.1 \mathrm{~m} \mathrm{~s}^{-1}$ at the bottom. The depth-averaged velocity was $0.06 \pm 0.09 \mathrm{~m} \mathrm{~s}^{-1}$ (Fig. 11), which is of the same order of magnitude as the observed mean velocity of $\sim 0.02 \mathrm{~m} \mathrm{~s}^{-1}$ at WC1. This suggests

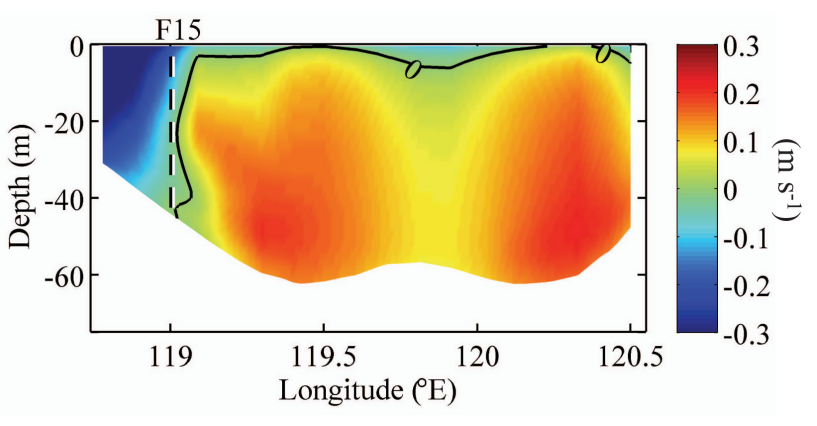

Fig. 11. The model-derived structure of current velocity $\left(\mathrm{m} \mathrm{s}^{-1}\right)$ along $24.6^{\circ} \mathrm{N}$ in the TWS in winter (December, January, and February). The negative/positive values indicate the southward/northward velocities. The zero contour appears as a heavy line. Also shown is the location of the station F15, which was the primary station where our model was validated in transport velocity. See text for details.

that the model results under climatological forcing predicts reasonable flow field.

To estimate the transport of the CCC, we integrated the modeled flow field over the entire water column within the CCC spanning between $119.0^{\circ} \mathrm{E}$ and $118.84^{\circ} \mathrm{E}$ with a width of $\sim 17.5 \mathrm{~km}$ (marked by the red solid line in Fig. 1c) and across a water depth of $25-44 \mathrm{~m}$. Note that $118.84^{\circ} \mathrm{E}$ was the model meridional velocity grid closest to land and was used as the edge of the CCC in our calculation. We derived a transport of $0.13 \pm 0.09 \mathrm{~Sv}$, which corresponds to a mean equatorward of $0.17 \pm 0.12 \mathrm{~m} \mathrm{~s}^{-1}$.

\subsection{DIN flux of the $\mathrm{CCC}$ and its contribution to the new productivity on the NESCS shelf}

The DIN flux of the CCC through the TWS could be derived from the average DIN concentration and the average $T$. Because we did not find noticeable inter-winter variations in DIN concentrations in the TWS segment of the CCC from our own observations or from the literature, we adopted the average DIN concentration of $11.0 \pm 2.0 \mu \mathrm{mol} \mathrm{L}^{-1}$ from our observations of the CCC in the winters of 2008 and 2009 and 
the modeled average $T$ of $0.13 \pm 0.09 \mathrm{~Sv}$, and derived a DIN flux of $1430 \pm 1024 \mathrm{~mol} \mathrm{~s}^{-1}$. Albeit the large uncertainty of the estimated DIN flux resulting from variations in both the DIN concentration and volume transport fluxes, this DIN flux was substantial as compared to the concurrent DIN discharge from the Changjiang in wintertime, which is estimated to be $\sim 760 \mathrm{~mol} \mathrm{~s}^{-1}$ (Liu et al., 2009). Because the DIN loading of the Pearl River is small in winter and PRP flows southwestward driven by the northeast monsoon in winter (Liu et al., 2009; Ou et al., 2009) with little contribution to the NESCS, and the winter monsoon favors coastal downwelling (S. M. Liu et al., 2010; Gan et al., 2013b), the CCC-supplied nutrients were critically important to the NESCS shelf, which would otherwise be low in productivity despite its favorable light and temperature conditions.

Assuming the CCC persists from December to February, its total DIN transport was calculated to be $11.12 \pm 7.96 \times 10^{9} \mathrm{molN}$. If we assumed a $\mathrm{C}: \mathrm{N}$ ratio of $106: 16$, this amount of DIN would be equivalent to $8.84 \pm 6.33 \times 10^{11} \mathrm{gC}$ being fixed on the NESCS shelf. Based upon our parallel study conducted on the same cruise in winter 2008, the NP and PP at station S608 (see location in Fig. 1b, water depth 106-118 m, or station S1 in Wang et al., 2012) on the NESCS shelf were measured to be about $0.15 \mathrm{gC} \mathrm{m}^{-2} \mathrm{~d}^{-1}$ and $0.51 \mathrm{gC} \mathrm{m}^{-2} \mathrm{~d}^{-1}$ (Wang et al., 2012). In a previous study, the NP and PP were measured at a station at water depth of $\sim 73 \mathrm{~m}$ on the NESCS shelf in winter 2004 to be $0.34 \mathrm{gC} \mathrm{m}^{-2} \mathrm{~d}^{-1}$ and $0.82 \mathrm{gC} \mathrm{m}^{-2} \mathrm{~d}^{-1}$ (Chen and Chen, 2006), slightly higher than those observed in winter 2008. Similarly, a winter PP of $\sim 0.8 \mathrm{gC} \mathrm{m}^{-2} \mathrm{~d}^{-1}$ was reported by Hao et al. (2007) for the inner NESCS shelf. Thus, we adopted an NP range of $0.15-0.34 \mathrm{gC} \mathrm{m}^{-2} \mathrm{~d}^{-1}$ and a PP range of $0.51-0.82 \mathrm{gC} \mathrm{m}^{-2} \mathrm{~d}^{-1}$. Given that the surface area of the NESCS shelf shallower than $100 \mathrm{~m}$ is $\sim 8.8 \times 10^{4} \mathrm{~km}^{2}$, we estimated that the CCC-carried DIN could have supported $33-74 \%$ of the NP and $14-22 \%$ of the $\mathrm{PP}$ in winter.

It is noted that the NESCS shelf is strongly impacted by the intrusion of the Kuroshio water of extremely low nutrients (Du et al., 2013) in its surface water, which could displace or dilute the nutrient-laden water of CCC. On the other hand, certain diapycnal mixing processes, such as tidal current, and/or internal waves might be able to transport nutrients from the Kuroshio subsurface water to the upper water column, which are yet to be quantified. Nevertheless, given the limited nutrient input into the NESCS shelf in winter, the CCC-transported nutrients should have been critical in sustaining the winter biological production as we observed.

\section{Summary and conclusions}

This study has highlighted that the monsoonal wind-driven CCC might be a primary conduit for nutrient transport from the ECS to the NESCS shelf. We estimated that the DIN flux carried by the CCC through the TWS was $1430 \pm 1024 \mathrm{~mol} \mathrm{~s}^{-1}$, which was very significant given the very limited nutrient influx into the NESCS shelf in winter. Such a DIN flux might have supported a carbon fixation of $8.84 \pm 6.33 \times 10^{11} \mathrm{gC}$, which corresponded to $33-74 \%$ of NP or $14-22 \%$ of PP on the NESCS shelf in winter.

This study has demonstrated that along-shore transport could indeed have important biogeochemical implications. In the present case, the southward nutrient transport from the north that was typically cold and had excess nutrients could significantly stimulate biological productivity downstream, thereby redistributing both nutrients and biomass.

It must be pointed out that the present estimate of nutrient transport is subject to a high degree of uncertainty. Longer term observations of both volume transport and nutrient distribution are needed to constrain better this important transport that has been often overlooked.

Acknowledgements. This research was funded by the National Basic Research Program of China (973 Program) through grants 2009CB421204 and 2009CB421201, and the Ocean Public Welfare Scientific Research Project, State Oceanic Administration, People's Republic of China through grant 200905012 (subtask no. 200905012-6). We thank X. Huang, and J. Yang for their help with ancillary data and sample collection. We are grateful to L. Liang for help in the modeling work. Author S. Jan calculated the flow volume transport using the current velocity profile data collected during the Taiwan Strait Nowcast (TSNOW) project with the collaboration of T. Y. Tang of NTU and S.-F. Lin of ITRI. We also thank the crew of R/V Dongfanghong II for their cooperation during the cruise. We thank J. Hodgkiss for his help with English. Constructive suggestions from two anonymous reviewers and K.-K. Liu have greatly improved the quality of the paper.

Edited by: K.-K. Liu

\section{References}

Chai, C., Yu, Z., Song, X., and Cao, X.: The status and characteristics of eutrophication in the Yangtze River (Changjiang) Estuary and the adjacent East China Sea, China, Hydrobiologia, 563, 313-328, 2006.

Chang, P.-H. and Isobe, A.: A numerical study on the Yangtze diluted water in the Yellow and East China Seas, J. Geophys. Res., 108, 3299, doi:10.1029/2002JC001749, 2003.

Chen, C.-T. A.: The Kuroshio intermediate water is the major source of nutrients on the East China Sea continental shelf, Oceanol. Acta, 19, 523-527, 1996.

Chen, C.-T. A.: Rare northward flow in the Taiwan Strait in winter: A note, Cont. Shelf Res., 23, 387-391, 2003.

Chen, C.-T. A.: Distributions of nutrients in the East China Sea and the South China Sea connection, J. Oceanogr., 64, 737-751, 2008.

Chen, Y.-L. L., and Chen, H.-Y.: Seasonal dynamics of primary and new production in the northern South China Sea: The significance of river discharge and nutrient advection, Deep-Sea Res. I, 53, 971-986, 2006. 
Chen, C.-T. A. and Wang, S.-L.: Carbon, alkalinity and nutrient budgets on the East China Sea continental shelf, J. Geophys. Res., 104, 20675-20686, 1999.

Chen, C.-T. A., Jan, S., Huang, T.-H., and Tseng, Y.-H.: Spring of no Kuroshio intrusion in the southern Taiwan Strait, J. Geophys. Res., 115, C08011, doi:10.1029/2009JC005804, 2010.

Chen, Y.-L. L., Chen, H.-Y., Lee, W.-H., Hung, C.-C., Wong, G. T. F., and Kanda, J.: New production in the East China Sea, comparison between well-mixed winter and stratified summer conditions, Cont. Shelf Res., 21, 751-764, 2001.

Chiang, K. P., Chou, Y. H., Chang, J., and Gong, G. C.: Winter distribution of diatom assemblages in the East China Sea, J. Oceanogr., 60, 1053-1062, 2004.

Du, C., Liu, Z., Dai, M., Kao, S.-J., Cao, Z., Zhang, Y., Huang, T., Wang, L., and Li, Y.: Impact of the Kuroshio intrusion on the nutrient inventory in the upper northern South China Sea: insights from an isopycnal mixing model, Biogeosciences, 10, 6419-6432, doi:10.5194/bg-10-6419-2013, 2013.

Fang, G., Wang, Y., Wei, Z., Fang, Y., Qiao, F., and Hu, X.: Interocean circulation and heat and freshwater budgets of the South China Sea based on a numerical model, Dynam. Atmos. Oceans, 47, 55-72, 2009.

Fu, Z., Hu, J., and Yu, G.: Seawater flux through Taiwan Strait, Chin. J. Oceanol. Limn., 9, 232-239, 1991.

Gan, J. and Allen, J. S.: On open boundary conditions for a limited-area coastal model off Oregon, Part 1: Response to idealized wind forcing, Ocean Model., 8, 115-133, doi:10.1016/j.ocemod.2003.12.006, 2005.

Gan, J., Liang, L., and Liu, Z.: Transport and exchange in China Seas: Modeling study, in preparation, 2013a.

Gan, J., Ho, H. S., and Liang, L.: Dynamics of intensified downwelling circulation over a widened shelf, J. Phys. Oceanogr., 43, 80-94, doi:10.1175/JPO-D-12-02.1, 2013b.

Gong, G.-C., Wen, Y.-H., Wang, B.-W., and Liu, G.-J.: Seasonal variation of chlorophyll $a$ concentration, primary production and environmental conditions in the subtropical East China Sea, Deep-Sea Res. II, 50, 1219-1236, 2003.

Gong, G.-C., Chang, J., Chiang, K.-P., Hsiung, T.-M., Hung, C.-C., Duan, S.-W., and Codispoti, L. A.: Reduction of primary production and changing of nutrient ratio in the East China Sea: Effect of the Three Gorges Dam?, Geophys. Res. Lett., 33, L07610, doi:10.1029/2006GL025800, 2006.

Gong, G.-C., Liu, K.-K., Chiang, K.-P., Hsiung, T.-M., Chang, J., Chen, C.-C., Hung, C.-C., Chou, W.-C., Chung, C.-C., Chen, H.Y., Shiah, F.-K., Tsai, A.-Y., Hsieh, C.-h., Shiao, J.-C., Tseng, C.-M., Hsu, S.-C., Lee, H.-J., Lee, M.-A., Lin, I.-I., and Tsai, F.: Yangtze River floods enhance coastal ocean phytoplankton biomass and potential fish production, Geophys. Res. Lett., 38, L13603, doi:10.1029/2011GL047519, 2011.

Guan, B. and Fang, G.: Winter counter-wind currents off the southeastern China coast: A review, J. Oceanogr., 62, 1-24, 2006.

Guo, X., Zhu, X.-H., Wu, Q.-S., and Huang, D.: The Kuroshio nutrient stream and its temporal variation in the East China Sea, J. Geophys. Res., 117, C01026, doi:10.1029/2011JC007292, 2012.

Hama, T., Shin, K. H., and Handa, N.: Spatial variability in the primary productivity in the East China Sea and its adjacent waters, J. Oceanogr., 53, 41-51, 1997.

Han, A., Dai, M., Kao, S.-J., Gan, J., Li, Q., Wang, L., Zhai, W., and Wang, L.: Nutrient dynamics and biological consumption in a large continental shelf system under the influence of both a river plume and coastal upwelling, Limnol. Oceanogr., 57, 486-502, 2012.

Hao, Q., Ning, X., Liu, C., Cai, Y., and Le, F.: Satellite and in situ observations of primary production in the northern South China Sea, Acta Oceanol. Sin., 29, 58-68, 2007 (in Chinese).

Hong, H., Chai, F., Zhang, C., Huang, B., Jiang, Y., and Hu, J.: An overview of physical and biogeochemical processes and ecosystem dynamics in the Taiwan Strait, Cont. Shelf Res., 31, S3-S12, 2011.

Hu, J., Kawamura, H., Hong, H., and Qi, Y.: A review on the currents in the South China Sea: Seasonal circulation, South China Sea warm current and Kuroshio intrusion, J. Oceanogr., 56, 607624, 2000.

Isobe, A.: Recent advances in ocean-circulation research on the Yellow Sea and East China Sea shelves, J. Oceanogr., 64, 569-584, 2008.

Jan, S. and Chao, S.-Y.: Seasonal variation of volume transport in the major inflow region of the Taiwan Strait: The Penghu Channel, Deep-Sea Res. II, 50, 1117-1126, 2003.

Jan, S., Chern, C.-S., and Wang, J.: A numerical study of currents in the Taiwan Strait during winter, Terr. Atmos. Ocean. Sci., 9, 615-632, 1998.

Jan, S., Sheu, D. D., and Kuo, H.-M.: Water mass and throughflow transport variability in the Taiwan Strait, J. Geophys. Res., 111, C12012, doi:10.1029/2006JC003656, 2006.

Jan, S., Tseng, Y.-H., and Dietrich, D. E.: Sources of water in the Taiwan Strait, J. Oceanogr., 66, 211-221, 2010.

Kao, S.-J., Lin, F.-J., and Liu, K.-K.: Organic carbon and nitrogen contents and their isotopic compositions in surficial sediments from the East China Sea shelf and the southern Okinawa Trough, Deep-Sea Res. II, 50, 1203-1217, 2003.

Keafer, B. A., Churchill, J. H., McGillicuddy Jr., D. J., and Anderson, D. M.: Bloom development and transport of toxic Alexandrium fundyense populations within a coastal plume in the Gulf of Maine, Deep-Sea Res. II, 52, 2674-2697, 2005.

Kim, D., Choi, S. H., Kim, K. H., Shim, J., Yoo, S., and Kim, C. H.: Spatial and temporal variations in nutrient and chlorophyll- $a$ concentrations in the northern East China Sea surrounding Cheju Island, Cont. Shelf Res., 29, 1426-1436, 2009.

Ladd, C., Stabeno, P., and Cokelet, E. D.: A note on cross-shelf exchange in the northern Gulf of Alaska, Deep-Sea Res. II, 52, 667-679, 2005.

Lee, H.-J. and Chao, S.-Y.: A climatological description of circulation in and around the East China Sea, Deep-Sea Res. II, 50, 1065-1084, 2003.

Liang, W.-D., Tang, T., Yang, Y., Ko, M., and Chuang, W.-S.: Upper-ocean currents around Taiwan, Deep-Sea Res. II, 50, 1085-1105, 2003.

Lin, S., Tang, T., Jan, S., and Chen, C.-J.: Taiwan Strait current in winter, Cont. Shelf Res., 25, 1023-1042, 2005.

Liu, J., Xu, K., Li, A., Milliman, J. D., Velozzi, D. M., Xiao, S., and Yang, Z.: Flux and fate of Yangtze River sediment delivered to the East China Sea, Geomorphology, 85, 208-224, 2007.

Lui, H.-K. and Chen, C.-T. A.: Shifts in limiting nutrients in an estuary caused by mixing and biological activity, Limnol. Oceanogr., 56, 989-998, 2011.

Liu, K. K., Tang, T., Gong, G.-C., Chen, L.-Y. L., and Shiah, F.K.: Cross-shelf and along-shelf nutrient fluxes derived from flow 
fields and chemical hydrography observed in the southern East China Sea off northern Taiwan, Cont. Shelf Res., 20, 493-523, 2000.

Liu, K. K., Chao, S. Y., Lee, H. J., Gong, G. C., and Teng, Y. C.: Seasonal variation of primary productivity in the East China Sea: A numerical study based on coupled physical-biogeochemical model, Deep-Sea Res. II, 57, 1762-1782, 2010.

Liu, S. M., Hong, G.-H., Zhang, J., Ye, X. W., and Jiang, X. L.: Nutrient budgets for large Chinese estuaries, Biogeosciences, 6 , 2245-2263, doi:10.5194/bg-6-2245-2009, 2009.

Liu, S. M., Guo, X., Chen, Q., Zhang, J., Bi, Y., Luo, X., and Li, J.: Nutrient dynamics in the winter thermohaline frontal zone of the northern shelf region of the South China Sea, J. Geophys. Res., 115, C11020, doi:10.1029/2009JC005951, 2010.

Lui, H.-K. and Chen, C.-T. A.: Shifts in limiting nutrients in an estuary caused by mixing and biological activity, Limnol. Oceanogr., 56, 989-998, 2011.

Ma, J., Yuan, D., and Liang, Y.: Sequential injection analysis of nanomolar soluble reactive phosphorus in seawater with HLB solid phase extraction, Mar. Chem., 111, 151-159, 2008.

Naik, H. and Chen, C.-T. A.: Biogeochemical cycling in the Taiwan Strait, Estuar. Coast. Shelf S., 78, 603-612, 2008.

Ou, S., Zhang, H., and Wang, D.: Dynamics of the buoyant plume off the Pearl River Estuary in summer, Environ. Fluid Mech., 9, 471-492, 2009.

Pan, A., Wan, X., Guo, X., and Jing, C.: Responses of the ZheMin coastal current adjacent to Pingtan Island to the wintertime monsoon relaxation in 2006 and its mechanism, Sci. China Ser. D., 42, 1317-1328, 2012.

Parsons, T. R., Maita, Y., and Lalli, C. M. (Eds.): A manual of chemical and biological methods for seawater analysis, Pergamon, 1984.

Qiu, Y., Li, L., Chen, C.-T. A., Guo, X., and Jing, C.: Currents in the Taiwan Strait as observed by surface drifters, J. Oceanogr., 67, 395-404, 2011.

Sasaki, H., Nonaka, M., Masumoto, Y., Sasai, Y., Uehara, H., and Sakuma, H.: An eddy-resolving hindcast simulation of the quasi global ocean from 1950 to 2003 on the Earth Simulator. In High Resolution Numerical Modelling of the Atmosphere and Ocean, edited by: Hamilton, K. and Ohfuchi, W., chapter 10, 157-185, Springer, New York, 2008.

Shaw, P. T.: The seasonal variation of the intrusion of the Philippine sea water into the South China Sea, J. Geophys. Res., 96, 821827, 1991.

Shchepetkin, A. F. and McWilliams, J. C.: The regional oceanic modeling system (ROMS): A split-explicit, free-surface, topography-following-coordinate oceanic model, Ocean Model., 9, 437-404, 2005.

Sugimoto, R., Kasai, A., Miyajima, T., and Fujita, K.: Transport of oceanic nitrate from the continental shelf to the coastal basin in relation to the path of the Kuroshio, Cont. Shelf Res., 29, 16781688, 2009.
Umezawa, Y., Yamaguchi, A., Ishizaka, J., Hasegawa, T., Yoshimizu, C., Tayasu, I., Yoshimura, H., Morii, Y., Aoshima, T., and Yamawaki, N.: Seasonal shifts in the contributions of the Changjiang River and the Kuroshio Current to nitrate dynamics at the continental shelf of the northern East China Sea based on a nitrate dual isotopic composition approach, Biogeosciences Discuss., 10, 10143-10188, doi:10.5194/bgd-10-10143-2013, 2013.

Wang, L., Lin, L., Xie, Y., and Huang, B.: A preliminary study on the new productivity and primary productivity of East China Sea and northern South China Sea in winter, J. Mar. Sci., 30, 59-66, 2012 (in Chinese).

Wang, X., Zhang, Y., and Liu, C.: Using fish conservation as object to estimate environmental flow in Jiaojiang River, Chin. J. EcoAgricul., 19, 712-717, 2011 (in Chinese).

Wang, Y. H., Jan, S., and Wang, D. P.: Transports and tidal current estimates in the Taiwan Strait from shipboard ADCP observations (1999-2001), Estuar. Coast. Shelf S., 57, 193-199, 2003.

Whitney, F. A., Crawford, W. R., and Harrison, P. J.: Physical processes that enhance nutrient transport and primary productivity in the coastal and open ocean of the subarctic NE Pacific, Deep-Sea Res. II, 52, 681-706, 2005.

Wollast, R.: The coastal organic carbon cycle: Fluxes, sources, and sinks, in: Ocean Margin Processes in Global Change, edited by: Mantoura, R. F. C., Martin, J. M., and Wollast, R., Wiley, New York, 365-381., 1991.

Wollast, R.: Interactions of carbon and nitrogen cycles in the coastal zone, in: Interactions of $\mathrm{C}, \mathrm{N}, \mathrm{P}$ and $\mathrm{S}$ biogeochemical cycles and global change, edited by: Wollast, R., Mackenzie, F. T., and Chou, L., Springer, Berlin, 195-210, 1993.

Wong, G. T. F., Chao, S.-Y., Li, Y.-H., and Shiah, F.-K.: The Kuroshio edge exchange process (KEEP) study-an introduction to hypotheses and highlights, Cont. Shelf Res., 20, 335-347, 2000.

Wu, C.-R. and Hsin, Y.-C.: Volume transport through the Taiwan Strait: A numerical study, Terr. Atmos. Ocean. Sci., 16, 377-391, 2005.

Wu, C.-R., Chao, S.-Y., and Hsu, C.: Transient, seasonal and interannual variability of the Taiwan Strait current, J. Oceanogr., 63, 821-833, 2007.

Yan, X.: Distribution, decadal changes and fluxes of dissolved nutrients in the Jiulong River Estuary, Southwestern Taiwan Strait, M S., thesis, Xiamen University, China, 40 pp., 2011 (in Chinese).

Yu, M.: Study on salt water transgression in north tributary of Minjiang River in winter, Mar. Sci. Bull., 11, 17-22, 1992 (in Chinese).

Zhang, J., Liu, S., Ren, J., Wu, Y., and Zhang, G.: Nutrient gradients from the eutrophic Changjiang (Yangtze River) Estuary to the oligotrophic Kuroshio waters and re-evaluation of budgets for the East China Sea Shelf, Prog. Oceanogr., 74, 449-478, 2007.

Zhu, D., Li, L., Li, Y., and Guo, X.: Seasonal variation of surface currents in the southwestern Taiwan Strait observed with HF radar, Chinese Sci. Bull., 53, 2385-2391, 2008. 